Волкова Н.I.,

кандидат економічних наук, доцент, Донецький національний університет імені Василя Стуса

ORCID: 0000-0003-3790-3636

n.volkova@donnu.edu.ua

Мухіна A.C.,

Донецький національний університет імені Василя Стуса mukhina.al@donnu.edu.ua

\title{
ВПРОВАДЖЕННЯ МОДЕЛІ ОЦІНКИ ВПЛИВУ РИЗИКІВ НА ФІНАНСОВУ СТІЙКІСТЬ АТ «ПУМБ»
}

У статті розглянуто основні фінансові ризики, щчо притаманні АТ «ПУМБ», а саме: кредитний ризик, ризик ліквідності, процентний ризик та валютний ризик. Встановлено, що виявом кредитного ризику є наявність проблемної та знеціненої заборгованості; передумовою появи ризику ліквідності $\epsilon$ переважсання короткострокових ресурсів над довгостроковими; протягом останніх років АТ «ПУМБ» був схильним до процентного ризику та у діяльність банку присутній значний валютний ризик, максимальний рівень якого спостерігався в 2017 році. Обтрунтовано необхідність побудови економіко-математичної моделі оцінки ризиків на фінансову стійкість банку, щуо дасть змогу визначити який з фінансових ризиків необхідно враховувати в першу чергу. За допомогою Microsoft Excel та програми Gretl проведено регресійний аналіз та спеціальні тести, що підтверджують якість моделі та можливість ї̈ використання. Побудовано прогноз індексу фінансової стійкості на майбутні роки, а саме на 2020-2024 рр., який показує можливий оптимістичний та песимістичний сценарій.

Ключові слова: фінансова стійкість, оцінка фінансових ризиків, кредитний ризик, ризик ліквідності, процентний ризик, валютний ризик, модель.

Рис. -5 , Табл. -3 , Літ. -15

Волкова Н.И.,

кандидат экономических наук, доцент,

Донецкий национальный университет имени Василия Стуса

ORCID: 0000-0003-3790-3636

n.volkova@donnu.edu.ua

Мухина А.C.,

Донецкий национальный университет имени Василия Стуса mukhina.al@donnu.edu.ua

\section{ВНЕДРЕНИЕ МОДЕЛИ ОЦЕНКИ ВЛИЯНИЯ РИСКОВ НА ФИНАНСОВУЮ УСТОЙЧИВОСТЬ АО «ПУМБ»}


В статье рассмотрены основные финансовые риски, присущчие $А O$ «ПУМБ», $а$ именно: кредитный риск, риск ликвидности, процентный риск и валютный риск. Установлено, что проявлением кредитного риска является наличие проблемной $u$ просроченной задолженности; причиной возникновения риска ликвидности является преобладание краткосрочных ресурсов над долгосрочными; в течение последних лет АО «ПУМБ» был склонен к прочентному риску и в деятельность банка присутствует значительный валютный риск, максимальный уровень которого наблюдался в 2017 году. Обоснована необходимость построения экономико-математической модели оценки рисков на финансовую устойчивость банка, что позволит определить который из финансовых рисков необходимо учитывать в первую очередь. С помощьью Microsoft Excel u программы Gretl выполнено регрессионный анализ и специальныле тесты, подтверждаюшие качество модели и возможность ее использования. Построен прогноз индекса финансовой устойчивости на будущче годы, а именно на 2020-2024 г2., который показывает оптимистичный и пессимистичный сценарий.

Ключевые слова: финансовая устойчивость, очуенка финансовых рисков, кредитный риск, риск ликвидности, процентный риск, валютный риск, модель.

Рис. - 5, Табл. - 3, Лит. -15

\author{
N. Volkova, \\ $\mathrm{PhD}$ in Economics, Associate Professor, \\ Vasyl' Stus Donetsk National University \\ ORCID: 0000-0003-3790-3636 \\ n.volkova@donnu.edu.ua
}

\author{
A. Mukhina,
}

Vasyl’ Stus Donetsk National University mukhina.al@donnu.edu.ua

\title{
INTRODUCTION OF THE MODEL OF RISK IMPACT ASSESSMENT ON FINANCIAL SUSTAINABILITY OF JSC FUIB
}

The article considers the main financial risks inherent in JSC FUIB, namely: credit risks, liquidity risks, interest rate risks and currency risks. It is established that the cause of credit risk is the presence of problem and impaired debt; a prerequisite for liquidity risk is the excess of short-term resources over long-term; in recent years, JSC FUIB is prone to interest rate risk and the bank has a significant currency risk, the maximum level of which was observed in 2017. The necessity of building an economic-mathematical model for assessing the impact of risks on the financial stability of the bank is substantiated. This model will allow to determine which of the financial risks must be considered in the first place to ensure the financial stability of the bank. Regression analysis and special tests were performed using Microsoft Excel and Gretl, to confirm the quality of the model and the possibility of its use. The forecast of the financial stability index for the coming years is constructed, namely for 2020-2024, which shows a possible optimistic and pessimistic scenario.

Keywords: financial stability, assessment of financial risk, credit risk, liquidity risk, interest rate risk, currency risk, model.

Fig. -5 , Tab. -3 , Ref. -15 
Постановка проблеми. Банківська діяльність $є$ однією з найважливіших галузей економіки так, як банки $є$ не тільки провідниками грошово-кредитної політики, але й мають важливе значення для суспільства. Очевидно, що одним із важливих завдань, що постають перед банківською установою є забезпечення фінансової стійкості, на що впливає не тільки платоспроможність, прибутковість та ліквідність комерційного банку, але й ризиковість діяльності. Відповідно, надійність та стійкість банківської установи напряму залежить від рівня управління ризиками.

Аналіз останніх досліджень та публікацій. Проблемі управління банківськими ризиками присвячені праці таких вітчизняних вчених як: Макаренко Ю. П., Бобиль В. В [1], Спіфанов А. О., Васильєва Т.А. [2], Примостка Л.О., Чуб П.М. [3], Кришталь Г. О. [4], Христенко О. В [5] та ін. Дослідженням фінансової стійкості банку та впливу на неї ризиків займались Дзюблюк, О.В [6], Пірог В. В. [7], Вовк В. Я. [8], Цебоноян С., Страхан П. [9], Даффі Д. [10], Джаріон П. [11], Канеман Д., Тверський А. [12], Хілсон Д., МюррейВебстер Р. [13], 14. Шнаттерлі К., Кларк Б. Б., Хау Дж., Девон М. Л. [14], Кайза С., Котунго М., Феорделізі Ф., Стефанеллі В. [15] та ін.

Мета статті полягає у побудові економіко-математичної моделі оцінки впливу ризиків на фінансову стійкість та ії впровадженні в діяльність АТ «ПУМБ».

Викладення основного матеріалу. Фінансова стійкість банку досить тісно пов'язана з банківськими ризиками, бо банки змушені працювати в умовах підвищеного ризику. Слід зазначити, що найбільший вплив на діяльність банківської установи, в тому числі АТ «ПУМБ», здійснюють фінансові ризики, а саме: кредитний ризик, ризик ліквідності, процентний ризик та валютний ризик.

Виявом кредитного ризику для АТ «ПУМБ» $є$ поява прострочених та знецінених кредитів. Незважаючи на зменшення обсягу прострочених та знецінених кредитів банку, їх частка в загальному обсязі наданих кредитів все ж залишається значною (рис.1).

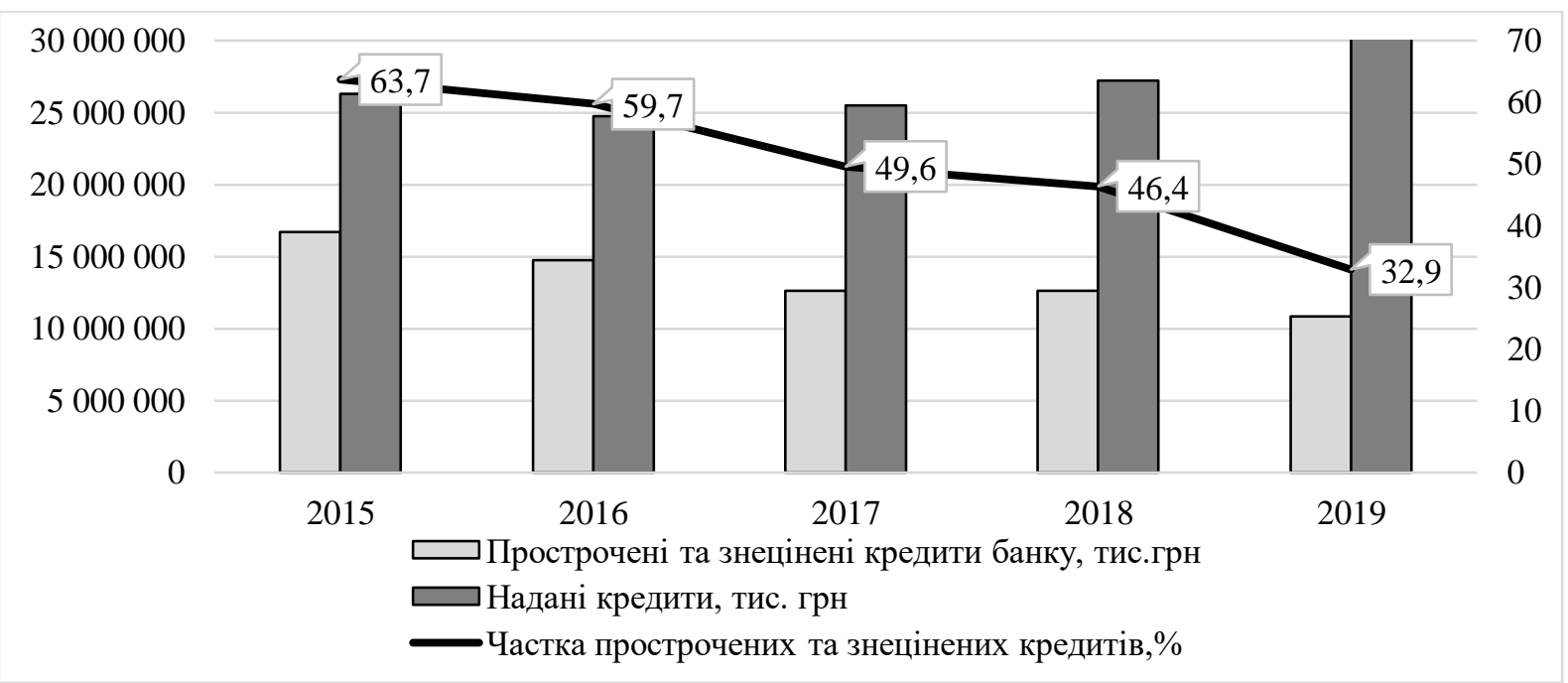

\section{Рисунок 1 - Динаміка прострочених та знецінених кредитів АТ «ПУМБ» протягом 2015-2019 pp.}

Як видно з рисунку 1, станом на кінець 2019 року частка прострочених та знецінених кредитів становить $32,9 \%$.

Щодо ризику ліквідності, то у АТ «ПУМБ» присутнє домінування короткострокових ресурсів над довгостроковими, що створює передумови до підвищення ризику ліквідності. Також в результаті проведення GAP-аналізу можемо 
спостерігати позитивний геп впродовж 2015-2019 pр., що вказує на наявність надлишку ліквідності (табл. 1).

Таблиця 1

GAP-аналіз ліквідності АТ «ПУМБ» впродовж 2015-2019 рр., тис. грн.

\begin{tabular}{|l|c|c|c|c|c|}
\hline \multicolumn{1}{|c|}{ Показник } & 2015 & 2016 & 2017 & 2018 & 2019 \\
\hline Активи & 35605790 & 42355645 & 44310587 & 47439368 & 52933856 \\
\hline Зобов'язання & 33759313 & 40272237 & 41299914 & 42993763 & 45631199 \\
\hline Розрив (GAP) & 1846477 & 2083408 & 3010673 & 4445605 & 7302657 \\
\hline Кумулятивний GAP & 1846477 & 3929885 & 6940558 & 11386163 & 18688820 \\
\hline
\end{tabular}

Зазначимо, АТ «ПУМБ» займає гроші на тривалий термін і надає кредити на короткий термін. Для того, щоб уникнути негативних наслідків банку необхідно ефективно використовувати свої ліквідні кошти.

Дослідження довело, протягом останніх років АТ «ПУМБ» був схильним до процентного ризику, реалізація якого впливає на чистий процентний дохід в межах одного року внаслідок зростання процентних ставок. Відповідно, станом на 31 грудня 2019 року процентний дохід банку може знизився на 4016 тис. грн.

Стрімке зростання валютного ризику в діяльності АТ «ПУМБ» можемо спостерігати починаючи з 2015 року (табл. 2).

Таблиця 2

Валютний ризик АТ «ПУМБ» впродовж 2015-2019 рр., тис. грн

\begin{tabular}{|l|c|c|c|c|c|}
\hline \multicolumn{1}{|c|}{ Показник } & 2015 & 2016 & 2017 & 2018 & 2019 \\
\hline $\begin{array}{l}\text { Всього валютний ризик без } \\
\text { врахування диверсифікації }\end{array}$ & 115642 & 81896 & 134338 & 31574 & 59462 \\
\hline Ефект від диверсифікації & 61212 & 16104 & 15322 & 24903 & 10542 \\
\hline $\begin{array}{l}\text { Валютний ризик з врахуванням } \\
\text { диверсифікації }\end{array}$ & 54430 & 65792 & 119016 & 6671 & 48920 \\
\hline
\end{tabular}

Дані таблиці 2 доводять, максимальний розмір валютного ризику протягом аналізованого періоду спостерігався у 2017 році та становив 119016 тис. грн після диверсифікації. У 2019 році розмір валютного ризику після диверсифікації становить 48 920 тис. грн, що на $40 \%$ менше ніж у 2017 році.

Вважаємо, наявність фінансових ризиків в діяльності банку може призвести не тільки до втрати доходів, але й стати причиною порушення фінансової стійкості, тому моделювання оцінки впливу ризиків на фінансову стійкість банківської установи $\epsilon$ досить важливим аспектом як для самого банку, так і для всієї банківської системи. Тому нами було побудовано економіко-математичну модель, яка дає змогу визначити, який з фінансових ризиків найбільше впливає на діяльність банку, а значить може стати загрозою у порушенні фінансової стійкості в майбутньому.

Першочергово в модель включено показники оцінки фінансових ризиків банку, що були розраховані за наступними формулами:

1. для процентного ризику:

$$
\frac{G A P \text { за процентними ставками }}{\text { Всього чутливих активів }}
$$

2. для ризику ліквідності: 


\section{GAP ліквідності \\ Всього фінансових активів}

3. для кредитного ризику:

Резерви під знеціненні та прострочені кредити

Кредитний протфель банку

4. для валютного ризику:

$\frac{\text { Валютна позиція банку за всіма валютами }}{\text { Монетарні активи банку }}$

Для побудови моделі були використані показники АТ «ПУМБ» за останні п’ять років. За результативну ознаку було обрано Y - скоринговий індекс фінансової стійкості банківської установи, що розрахований аналітичним відділом YouControl. Для аналізу використані показники оцінки фінансових ризиків: X1 - процентний ризик; X2 - ризик ліквідності; X3 - кредитний ризик; X4 - валютний ризик.

Користуючись редактором Microsoft Excel, будуємо багатофакторну регресію та кореляційну матрицю для поетапного вилучення факторів. У таблиці 3 наведені дані для побудови багатофакторної моделі регресії.

Таблиця 3

Вихідні дані для побудови моделі багатофакторної регресії

\begin{tabular}{|c|c|c|c|c|c|}
\hline Рік & $\begin{array}{c}\text { Ү } \\
\text { Індекс } \\
\text { фінансової } \\
\text { стійкості }\end{array}$ & $\begin{array}{c}\text { Хроцентний } \\
\text { ризик }\end{array}$ & $\begin{array}{c}\text { Х2 } \\
\text { Ризик } \\
\text { ліквідності }\end{array}$ & $\begin{array}{c}\text { Х3 } \\
\text { Кредитний } \\
\text { ризик }\end{array}$ & $\begin{array}{c}\text { Х4 } \\
\text { Валютний } \\
\text { ризик }\end{array}$ \\
\hline 2015 & 1,56 & 0,0451 & 0,0519 & 0,4006 & 0,0962 \\
\hline 2016 & 1,75 & 0,0071 & 0,0492 & 0,4221 & 0,0095 \\
\hline 2017 & 1,83 & $-0,0377$ & 0,0679 & 0,3038 & 0,0077 \\
\hline 2018 & 2,07 & $-0,0319$ & 0,0937 & 0,1629 & 0,0091 \\
\hline 2019 & 2,32 & $-0,0142$ & 0,1380 & 0,2329 & 0,0426 \\
\hline
\end{tabular}

Перевірку факторів на наявність мультиколінеарності здійснюємо шляхом побудови матриці парних кореляцій. Завдяки даній матриці встановлено, що фактори X1 (процентний ризик) та Х3 (кредитний ризик) сильно корелюють з іншими даними, тому відкидаємо їх.

За допомогою інструменту аналізу «Регресія» проведено регресійний аналіз (рис.4). 3 отриманого аналізу модель має вигляд:

$$
Y=1.3768+7.4728 * X 2-2.1093 * X 4
$$

Отримане рівняння доводить, якщо показник оцінки ризику лік збільшиться на 1 пункт, то індекс фінансової стійкості збільшиться на 7,4728 пункти, відповідно якщо показник оцінки валютного ризику збільшиться на 1 пункт, то індекс фінансової стійкості банку зменшиться на 2,1093 пункти.

Коефіцієнт детермінації становить (R2) 0,99347, тобто отримане рівняння регресії пояснює коливання результативної ознаки «У» на 99,35\%, а на фактори, що не враховані в моделі припадає всього 0,65\%. Тому модель можна використовувати для подальшого економічного аналізу і прогнозу. 


\begin{tabular}{|c|c|c|c|c|c|c|c|c|}
\hline \multicolumn{9}{|c|}{ грессионная статистика } \\
\hline \multicolumn{9}{|c|}{ Множестве 0,9967323} \\
\hline \multicolumn{9}{|c|}{ R-квадрат 0,9934753} \\
\hline \multicolumn{9}{|c|}{ Нормирова 0,9869506} \\
\hline \multicolumn{9}{|c|}{ Стандартн: $\quad 0,0337$} \\
\hline \multicolumn{9}{|c|}{ Наблюденг: } \\
\hline \multicolumn{9}{|c|}{ Дисперсионный анализ } \\
\hline & $d f$ & $S S$ & $M S$ & $F$ & \multicolumn{4}{|l|}{ чачииость $F$} \\
\hline Регрессия & 2 & 0,3458486 & 0,1729243 & 152,2637 & 0,0065247 & & & \\
\hline Остаток & 2 & 0,0022714 & 0,0011357 & & & & & \\
\hline Итого & 4 & 0,34812 & & & & & & \\
\hline Kos & өффиичиенп & артная ои & татистик & -Значение & Іижние $95 \%$ & хние $95 \%$ & crue 95,0 & ние $95,0^{\circ}$ \\
\hline Y-пересече & 1,3768 & 0,0435 & 31,6382 & 0,0010 & 1,1896 & 1,5641 & 1,1896 & 1,5641 \\
\hline Переменна & 7,4728 & 0,4591 & 16,2758 & 0,0038 & 5,4973 & 9,4484 & 5,4973 & 9,4484 \\
\hline Переменна. & $-2,1093$ & 0,4427 & $-4,7646$ & 0,0413 & $-4,0141$ & $-0,2045$ & $-4,0141$ & $-0,2045$ \\
\hline
\end{tabular}

Рисунок 2 - Регресійний аналіз моделі

Також зробимо перевірку значущості коефіцієнтів отриманого рівняння. Для цього перевіримо виконання нерівності $\mathrm{P}(\mathrm{t}<\mathrm{tj}$ факт.) $\leq \alpha, \mathrm{j}=1,4$ (де $\alpha=0,05$ заданий рівень значимості). У стовпці «Р-значення» для обраних факторів всі значення менші заданого рівня значущості $\alpha=0,05$. Це означає, що всі коефіцієнти регресії статистично значущі 3 достовірністю 95\%. Значення середньої помилки становить 0,86\%, тобто в середньому розрахункові значення відхиляються від фактичних на $0,86 \%$ (рис.5). Оскільки виконується умова $0,86 \%<7 \%$, то можемо стверджувати, що якість моделі висока.

\begin{tabular}{|r|r|r|r|r|}
\hline \multicolumn{1}{|l|}{ ВЫВОД ОСТАТКА } & & & \\
\hline Наблюдениєедсказанноє Остатки & \multicolumn{1}{|c|}{$Y$} & \multicolumn{1}{l|}{ Оi } \\
\hline 1 & 1,5615 & $-0,0015$ & 1,56 & 0,0010 \\
\hline 2 & 1,7243 & 0,0257 & 1,75 & 0,0147 \\
\hline 3 & 1,8682 & $-0,0382$ & 1,83 & 0,0209 \\
\hline 4 & 2,0580 & 0,0120 & 2,07 & 0,0058 \\
\hline 5 & 2,3179 & 0,0021 & 2,32 & 0,0009 \\
\hline
\end{tabular}

\section{Рисунок 3 - Середня відносна помилка апроксимації побудованої моделі}

За допомогою програми Gretl, що використовується для економетричного моделювання, проведено перевірку на гетероскедастичність за тестом Бріша-Пегана. Результати тесту показують, що Хи-квадрат розрахунковий становить 2,04239, a pзначення дорівнює 0,36016. Оскільки р-значення 0,36016 більше за 0,05, а Хи-квадрат розрахунковий менший за табличний, що становить 5,99, то приймається нульова гіпотеза про відсутність гетероскедастичності. Так як, гетероскедастичність це найхарактерніша помилка для факторних регресійних моделей, тому доцільно проводити кілька тестів, щоб виключити або підтвердити ії наявність. Тому нами було проведено ще 2 тести, а саме: робастний варіант Коенкера (Koenker) та тест Вайта. Вони також підтвердили відсутність гетероскедастичності (рис.4).

Отже дослідження довело, що дану модель оцінки впливу ризиків на фінансову стійкість банківської установи можна використовувати в подальшому економічному аналізі та прогнозі. Оскільки коефіцієнт детермінації становить 99\%, усі коефіцієнти використані в моделі є значущі, якість модель знаходиться на високому рівні та відсутня гетероскедастичність. 


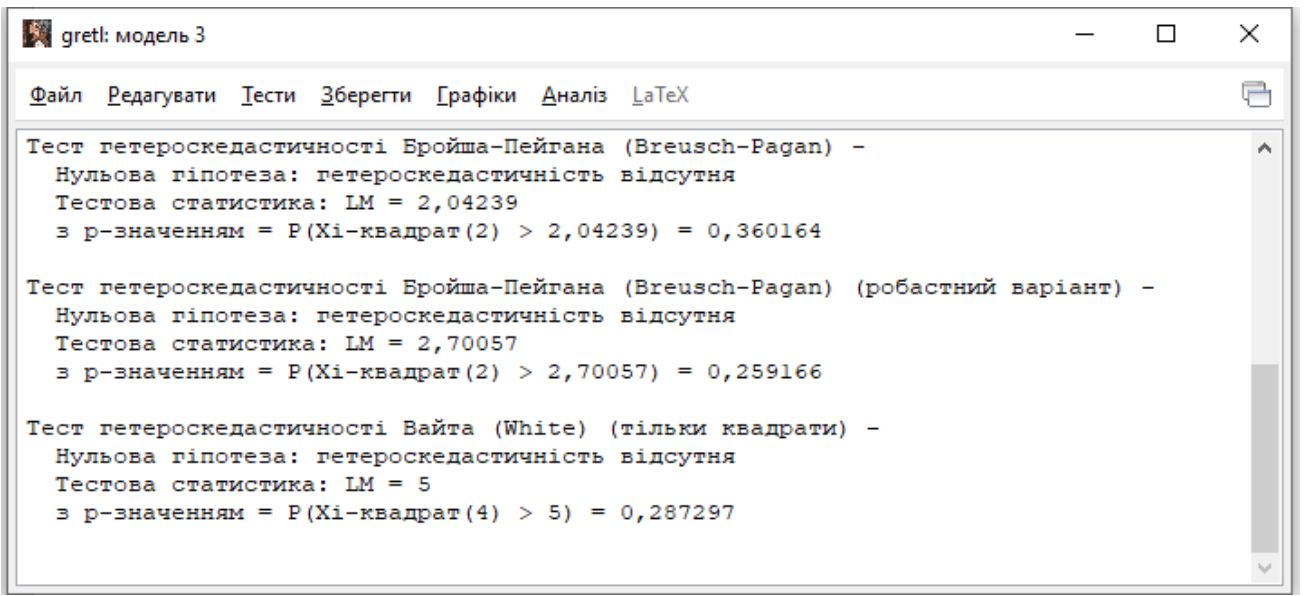

\section{Рисунок 4 - Результати тестів на гетероскедастичність факторної моделі}

Обов'язковим результатом будь-якої економіко-математичної моделі є отримання прогнозу на майбутні роки. На рисунку 5 наведений прогноз індексу фінансової стійкості АТ «ПУМБ» до 2024 року включно.

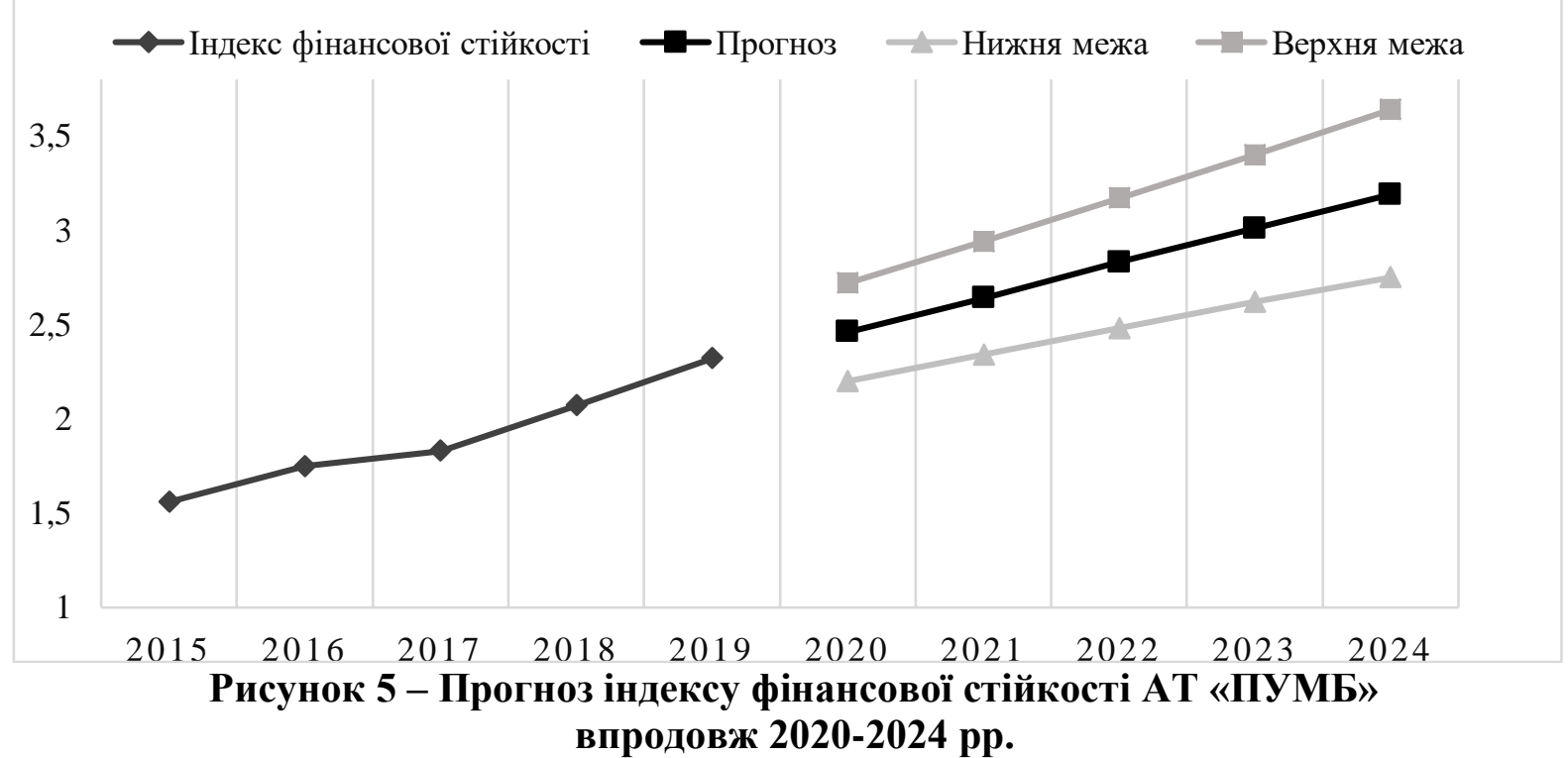

Можемо спостерігати зростання індексу фінансової стійкості АТ «ПУМБ», за даними прогнозу індекс досягне позначки 3,19 у 2020 році. При злагодженій роботі ризик-менеджменту банку можливий оптимістичний прогноз, при якому індекс фінансової стійкості досягне верхньої межі та у 2024 році становитиме 3,64 . У свою чергу, причиною зменшення індексу фінансової стійкості протягом майбутніх років може стати наявність значного валютного ризику, адже відповідно до побудованої моделі, збільшення показника оцінки валютного ризику на 1 пункт призведе до зменшення індексу фінансової стійкості на 2,1093 пункти. При песимістичному прогнозі у 2024 році індекс фінансової стійкості буде знаходитись у нижній межі та становитиме 2,75 .

Впровадження даної моделі у роботі АТ «ПУМБ» дасть змогу ризик-менеджменту банку вчасно реагувати на наявність ризиків та визначити, який ризик здійснює найбільший вплив на фінансову стійкість банку. А також, завдяки побудованому 
прогнозу працівники банку зможуть виявити можливі коливання індексу фінансової стійкості в майбутньому.

Висновки. За результатами побудованої моделі встановлено, що фінансова стійкість АТ «ПУМБ» вперш за все залежить від валютного ризику та ризику ліквідності. Самі ці ризики потребують негайної реакції з боку ризик-менеджменту банку та впровадження конкретних заходів щодо їх зниження. Для зниження рівня валютного ризику банку необхідно використовувати такі методи зниження як резервування та лімітування, а також здійснити заходи щодо збалансування активів та пасивів для боротьби з надлишком ліквідності. Практична реалізація зазначених методів в діяльності АТ «ПУМБ» буде предметом нашого дослідження в подальшому.

\section{СПИСОК ВИКОРИСТАНИХ ДЖЕРЕЛ}

1. Макаренко Ю. П., Бобиль В. В. Управління фінансовими ризиками банків: монографія, за ред. д-ра екон. наук, проф. Ю. П. Макаренко. Дніпропетровськ : Герда , 2014. - 266 c.

2. Спіфанов А. О., Васильєва Т.А., Козьменко С. М., та ін. Управління ризиками банків: монографія у 2 томах, за ред. д-ра екон. наук, проф. А. О. Спіфанова і д-ра екон. наук, проф. Т. А. Васильєвої. Суми : ДВНЗ “УАБС НБУ”, 2012. 299 с.

3. Примостка Л.О., Чуб П.М., Карчева Г. Т. Управління банківськими ризиками: навч. посіб., за заг. ред. д-ра екон. наук, проф. Л. О. Примостки. К. : КНЕУ, 2007. 600 с.

4. Кришталь Г. О. Управління фінансовими ризиками комерційних банків. Вісник Університету банківської справи Національного банку Украӥни. 2015. № 1. С. 179-184. 5. Христенко О. В., Федій О. В. Теоретичні основи системи управління ризиками в діяльності банку. Фінансовий простір. 2018. № 2. С. 161-169.

6. Дзюблюк, О.В., Михайлюк Р.В. Фінансова стійкість банків як основа ефективного функціонування кредитної системи: монографія. Тернопіль, 2009. 257 с.

7. Пірог В. В. Вплив ризиків на фінансову стійкість комерційного банку. Вісник Чернігівського державного технологічного університету. Серія : Економічні науки. 2014. № 2. C. 173-178.

8. Вовк В. Я., Дмитрик Ю. В. Забезпечення фінансової стійкості банківської системи в умовах кризи. Фінанси, банки, інвестиції. 2011. № 2. С. 43

9. Cebenoyan S., Strahan P. Risk Management, Capital Structure and Lending at Banks. Journal of Banking and Finance. 2004. № 28. P. 19-43.

10. Duffie D. Innovations in Credit Risk Transfer: Implications for Financial Stability. Stanford University, Draft: July 2, 2007. - 47 p.

11. Jorion, P. Risk management lessons from the credit crisis. European Financial Management. 2009. №15 (5), P. 923-933.

12. Kahneman, D., \& Tversky, A. (2013). Prospect theory: An analysis of decision under risk. Handbook of the fundamentals of financial decision making. 2013. Part I. P. 99-127.

13. Hillson D., Murray-Webster R. Understanding and Managing Risk Attitude. Gower Publishing, Ltd., 2007. 302 p.

14. Schnatterly, K., Clark, B. B., Howe, J., \& DeVaughn, M. L. (2018). Regulatory and governance impacts on bank risk-taking. Risk Management. 2018. №1. P. 1-24. 
15. Caiazza, S., Cotugno, M., Fiordelisi, F., \& Stefanelli, V. The spillover effect of enforcement actions on bank risk-taking. Journal of Banking \& Finance. 2018. №91. P. 146159.

\section{REFERENCES}

1. Makarenko, Yu. P. \& Bobyl, V. V. (2014). Upravlinnia finansovymy ryzykamy bankiv. Dnipropetrovsk : Herda [in Ukrainian].

2. Yepifanov, A. O., Vasylieva, T. A. \& Kozmenko, S. M. (2012). Upravlinnia ryzykamy bankiv. Sumy : DVNZ «UABS NBU» [in Ukrainian].

3. Prymostka, L.O., Chub, P.M. \& Karcheva, H. T. (2007). Upravlinnia bankivskymy ryzykamy: navch. posib. Kyiv: KNEU [in Ukrainian].

4. Kryshtal H. O. (2015). Upravlinnia finansovymy ryzykamy komertsiinykh bankiv. Visnyk Universytetu bankivskoi spravy Natsionalnoho banku Ukrainy. 1, 179-184 [in Ukrainian].

5. Khrystenko O. V. \& Fedii O. V. (2018). Teoretychni osnovy systemy upravlinnia ryzykamy v diialnosti banku. Finansovyi prostir. 2, 161-169 [in Ukrainian].

6. Dziubliuk, O.V. \& Mykhailiuk R.V. (2009). Finansova stiikist bankiv yak osnova efektyvnoho funktsionuvannia kredytnoi systemy. Ternopil, [in Ukrainian].

7. Piroh V. V. (2014). Vplyv ryzykiv na finansovu stiikist komertsiinoho banku. Visnyk Chernihivskoho derzhavnoho tekhnolohichnoho universytetu. Seriia : Ekonomichni nauky. 2. 173-178 [in Ukrainian].

8. Vovk V. Ya. \& Dmytryk Yu. V. (2011). Zabezpechennia finansovoi stiikosti bankivskoi systemy v umovakh kryzy. Naukovyi visnyk: Finansy, banky, investytsii. 2. 41-44 [in Ukrainian].

9. Cebenoyan S., Strahan P. Risk Management, Capital Structure and Lending at Banks. Journal of Banking and Finance. 2004. № 28. P. 19-43.

10. Duffie D. Innovations in Credit Risk Transfer: Implications for Financial Stability. Stanford University, Draft: July 2, 2007. -47 p.

11. Jorion, P. Risk management lessons from the credit crisis. European Financial Management, 2009. №15 (5), P. 923-933.

12. Kahneman, D., \& Tversky, A. (2013). Prospect theory: An analysis of decision under risk. Handbook of the fundamentals of financial decision making, 2013. Part I. P. 99-127.

13. Hillson D., Murray-Webster R. Understanding and Managing Risk Attitude. Gower Publishing, Ltd., 2007. 302 p.

14. Schnatterly, K., Clark, B. B., Howe, J., \& DeVaughn, M. L. (2018). Regulatory and governance impacts on bank risk-taking. Risk Management, 2018. №1. P. 1-24.

15. Caiazza, S., Cotugno, M., Fiordelisi, F., \& Stefanelli, V. The spillover effect of enforcement actions on bank risk-taking. Journal of Banking \& Finance, 2018. №91. P. 146159. 